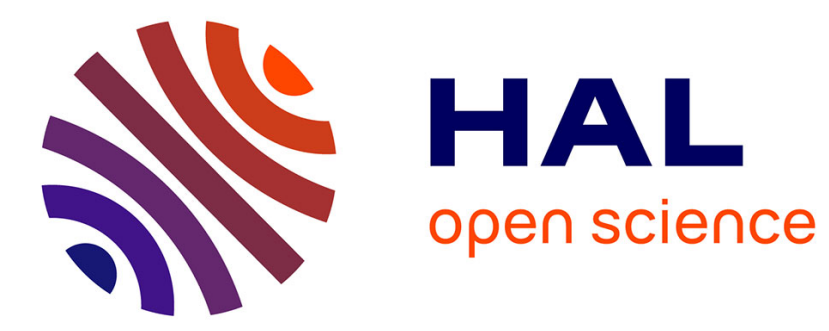

\title{
ICT and Sustainability: Looking Beyond the Anthropocene
}

\author{
Maja van Der Velden
}

\section{To cite this version:}

Maja van Der Velden. ICT and Sustainability: Looking Beyond the Anthropocene. 13th IFIP International Conference on Human Choice and Computers (HCC13), Sep 2018, Poznan, Poland. pp.166-180, 10.1007/978-3-319-99605-9_12 . hal-02001939

\section{HAL Id: hal-02001939 \\ https://hal.inria.fr/hal-02001939}

Submitted on 31 Jan 2019

HAL is a multi-disciplinary open access archive for the deposit and dissemination of scientific research documents, whether they are published or not. The documents may come from teaching and research institutions in France or abroad, or from public or private research centers.
L'archive ouverte pluridisciplinaire HAL, est destinée au dépôt et à la diffusion de documents scientifiques de niveau recherche, publiés ou non, émanant des établissements d'enseignement et de recherche français ou étrangers, des laboratoires publics ou privés. 


\title{
ICT and Sustainability: Looking beyond the Anthropocene
}

\author{
Maja van der Velden ${ }^{[0000-0002-9947-5692]}$ \\ University of Oslo \\ majava@ifi.uio.no
}

\begin{abstract}
This paper investigates the relation between information and communication technology and sustainability through two frameworks that promote sustainable development: the Sustainable Development Goals (SDGs) and Doughnut Economics. The instrumentalist technology perspective underlying the SDGs, guiding the perceived universality of ICT, presents ICT as a neutral tool. Doughnut Economics enables a more integrative approach, making the unsustainability of ICT itself visible. What these frameworks have in common is that they are located in the discourse of the Anthropocene. Feminist perspectives on this epoch by Donna Haraway and Anna Tsing focus the attention on different figures, rhythms, and futures made invisible by the centrality of the human species in the debates on the future of our planet. The idea that humanswith-technology will get us out the predicament of the Anthropocene needs urgent refinement and critical investigation.
\end{abstract}

Keywords: Doughnut Economics, Feminist Techoscience, Planetary Boundaries, Technological Anthropocene, Sustainability

\section{Introduction}

This paper presents a discussion of the relations between Information and Communication Technology (ICT) and sustainability through the perspective of two frameworks for sustainable development, the United Nations Sustainable Development Goals (SDGs) and Doughnut Economics [1]. The SDGs are a set of goals to "end poverty, protect the planet, and ensure prosperity for all as part of a new sustainable development agenda" [2]. Doughnut Economics is concerned with socially, environmentally, and economically sustainable development. Doughnut economics is presented by a doughnut-shaped visualization, in which the outer ring of the doughnut consists of nine planetary boundaries, which form the ecological ceiling for all life on or planet, and the inner ring as twelve key social and economic indicators, which form the social foundation for human life on the planet (see Fig. 1).

This discussion is situated within feminist perspectives on the Anthropocene. The Anthropocene is generally understood as a geological epoch in which the impacts of human activity dominate. Feminist technoscience problematize binaries that characterize the Anthropocene discourse, such as human/nonhuman and economy/ecology. 
This paper is part of an international research project called Sustainable Market Actors for Responsible Trade (SMART). Within this project, I focus on a particular ICT, the mobile phone. In our research we take a lifecycle approach, that means that we consider an ICT not only as a thing that is produced and consumed, but also as an ecology or assemblage of design (e.g., esthetics, functions, forms, uses), materials (e.g., minerals, metals, chemicals), humans (e.g., miners, workers, users), nonhumans (e.g., forests, fish, water, food, cattle, materials), values (e.g., just, fair, smart, green, fast, circular), politics (e.g., policies, laws), visions (e.g., good life, future), etc.

We actively use the doughnut-shaped visualization (see Fig. 1) to better understand the unsustainabilities found in the lifecycle of the mobile phone. We implemented in the SMART project a so-called hotspots analysis [3], a qualitative analysis, which resulted in the identification of environmental and social impacts in each of the mobile phone life cycle phases. We mapped these against the ecological foundation with the nine planetary boundaries (climate change, ocean acidification, chemical pollution, etc.) and against the social foundation, consisting of twelve key social and economic indicators (water, food, health, etc.). Through a weighing process we were able to find the most severe impacts on these boundaries and indicators, which we called hotspots.

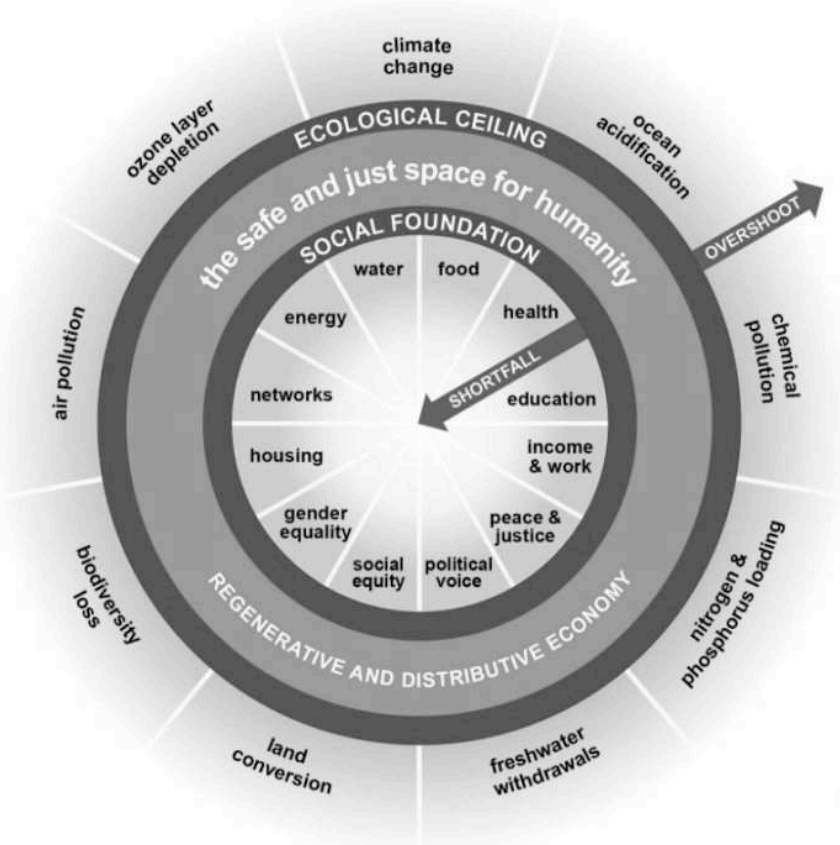

Fig. 1. The Doughnut [1]

As a socio-ecological system, the doughnut helped us to visualize the multiple ways in which humans and nonhumans interact in the mobile phone life cycle. At the 
same time, the doughnut, as 'The Safe and Just Space for Humanity', privileges humans. For example, Raworth asks: "Can we live in the doughnut?" [4] ${ }^{1}$. In this paper I will explore the human-centeredness that underlies the Doughnut and the SDGs, while staying close to my original concern, the relation between ICT and sustainability.

The other binary made visible by the doughnut is that of economy versus ecology. The question here is about 'who' will sort out what is good for the ecology and what is good for the economy? I will problematize this question through a brief discussion of one of the hotspots found in our research, namely chemical pollution as a result of the informal recycling of mobile phones and other electronics in Ghana.

The remainder of the paper is as follows. I will explore the Sustainable Development Goals in Section 2 and the doughnut in Section 3. In Section 4 I will introduce the perspectives of Donna Haraway and Anna Tsing on the Anthropocene in order to question some of the binaries found in the sustainable development discourse. I will conclude this paper with some final remarks on ICT and sustainability.

\section{The Sustainable Development Goals}

\subsection{ICT and Sustainable Development}

Two lines of inquiry can be distinguished in research on ICT and sustainability. In the first one, and the most developed one, ICT is seen as an enabler of sustainable development, but is itself not an object of investigation. Since 1995, with the establishment of the United Nations Commission on Science and Technology for Development (UNCSTD) Working Group on IT and Development, ICT has been on the UN's development agenda. For example, ICT is perceived as a "catalyst for sustainable development" [6] or as having the capacity to "deliver the SDGs" [7]. The International Telecommunications Union (ITU) runs a campaign, ICT for a Sustainable World \#ICT4SDG - and has developed an ICT toolkit for every SDG [8]. Scholarly research into ICT and development increased significantly with the start of the $21^{\text {st }}$ century, with the notion of ICT for sustainable development following soon after.

In the second line of inquiry, the sustainability of ICT itself is considered. This has not been a topic on the UN's development agenda and received initially less attention in scholarly circles. However, reports by civil society organisations on, for example, mining in conflict areas, working conditions in the electronics industry, and environmental degradation as a result of informal recycling practices, brought the unsustainability of ICTs to the foreground [9-13]. Our research in the SMART project is situated within this discourse.

The distinction between sustainable ICT and ICT for sustainability can also be found in the Sustainable Development Goals (SDGs) (see Fig. 2). The SDGs are a collection of 17 goals, with 169 associated targets and 304 indicators, set by the Unit-

\footnotetext{
${ }^{1}$ Similarly, we can ask: Can we design for living in the doughnut [5]?
} 
ed Nations in 2015. The SDGs are perceived as global and universal, promoting sustainable development in all countries.

ICTs are seen as central to achieving the Sustainable Development Goals (SDGs) and are specifically mentioned in Goals 4, 5, 9, and 17 and their targets or indicators (see Table 1).
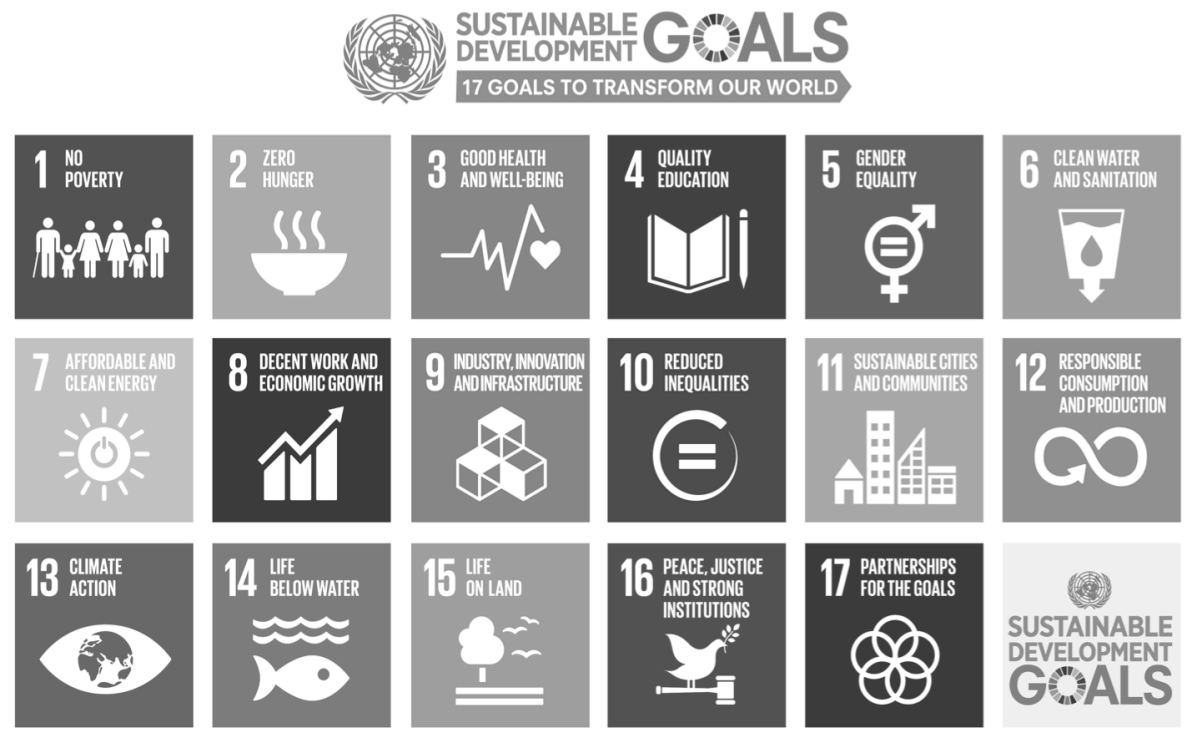

(79)

SUSTAINABLE DEVELOPMENT GALS

Fig. 2. United Nations Sustainable Development Goals

Table 1. ICTs and the Sustainable Development Goals

\begin{tabular}{l} 
Goal \\
\hline 4. Quality Education: Ensure inclusive \\
and equitable quality education and pro- \\
mote lifelong learning opportunities for \\
all
\end{tabular}
all

\section{Targets and Indicators}

Target 4.b. By 2020, substantially expand globally the number of scholarships available to developing countries, in particular least developed countries, small island developing States and African countries, for enrolment in higher education, including vocational training and information and communications technology, technical, engineering and scientific programmes, in developed countries and other developing countries Indicator 4.4.1. Proportion of youth and adults with information and communications technology (ICT) skills, by type of skill

5. Gender Equality: Achieve gender Target 5.b. Enhance the use of enabling equality and empower all women and technology, in particular information 


\begin{tabular}{l|l}
\hline girls & $\begin{array}{l}\text { and communications technology, to } \\
\text { promote the empowerment of women }\end{array}$ \\
\hline $\begin{array}{l}\text { 9. Industry, Innovation, and Infra- } \\
\text { structure: Build resilient infrastructure, } \\
\text { promote inclusive and sustainable indus- } \\
\text { trialization and foster innovation }\end{array}$ & $\begin{array}{l}\text { Target 9.c. Significantly increase access } \\
\text { to information and communications } \\
\text { technology and strive to provide univer- } \\
\text { sal and affordable access to the Internet } \\
\text { in least developed countries by 2020 }\end{array}$ \\
\hline $\begin{array}{l}\text { 17. Partnerships for the Goals: } \\
\text { Strengthen the means of implementation } \\
\text { and revitalize the Global Partnership for } \\
\text { Sustainable Development }\end{array}$ & $\begin{array}{l}\text { Target 17.8. Fully operationalize the } \\
\text { technology bank and science, technology } \\
\text { and innovation capacity-building mecha- } \\
\text { nism for least developed countries by } \\
\text { 2017 and enhance the use of enabling } \\
\text { technology, in particular information } \\
\text { and communication technology. }\end{array}$
\end{tabular}

The second perspective, the need for ICT itself to be sustainable, is only indirectly mentioned in Sustainable development Goal 8 and 12 (see Table 2).

Table 2. Sustainability of ICTs

\begin{tabular}{l}
\hline \multicolumn{3}{c}{ Goal } \\
\hline 8. Decent Work and Economic \\
Growth: Promote sustained, inclusive, \\
and sustainable economic growth, full \\
and productive employment and decent \\
work for all. \\
12. Responsible Consumption and \\
Production:
\end{tabular}

Target 8.4. Improve progressively,

through 2030, global resource efficiency in consumption and production and endeavour to decouple economic growth from environmental degradation, in accordance with the 10-Year Framework of Programmes on Sustainable Consumption and Production, with developed countries taking the lead.

Target 12.2. By 2030, achieve the sustainable management and efficient use of natural resources

Target 12.4. By 2020, achieve the environmentally sound management of chemicals and all wastes throughout their life cycle, in accordance with agreed international frameworks, and significantly reduce their release to air, water and soil in order to minimize their adverse impacts on human health and the environment.

Target 12.5 . By 2030, substantially reduce waste generation through prevention, reduction, recycling and reuse 


\subsection{An Instrumental Understanding of ICT}

There are several lines of critique developed around the SDGs. The main one is that the SDGs may promote increased growth, consumption, and production, while failing to address the limits of our planet:

"Unfortunately, "sustainable development," as advocated by most natural, social, and environmental scientists, is an oxymoron. Continual population growth and economic development on a finite Earth are biophysically impossible. They violate the laws of physics, especially thermodynamics, and the fundamental principles of biology. Population growth requires the increased consumption of food, water, and other essentials for human life. Economic development requires the increased use of energy and material resources to provide goods, services, and information technology" [14]

If economic growth, as part of sustainable development, is "impossible", what are the consequences of this understanding for the responsible production and consumption of ICTs? For example, can we call it sustainable ICT, when we use it for green data centres (sustainable development), whose server capacity is used for accelerating unsustainable consumption? Can we call for slow and fair ICT [15], if we don't know if our planet can sustain any more ICT?

A critique more specific to ICTs is that the SDGs are based on an instrumental understanding of technology; ICT are presented as neutral, universal tools to achieve sustainable development. Feenberg [16] presents four characteristics of this instrumentalist perspective: i) technology is indifferent to the ends to which it is employed; ii) technology is indifferent to politics, which facilitates its transfer to other social contexts; iii) technologies represent scientific ideas, which will be maintained in other social contexts; iv) from the universality of technology follows that "the same standards of measures can be applied in different settings. Thus technology is routinely said to increase productivity in labour in different countries, different eras, and different civilizations" [16, p. 6-7]. The perceived neutrality and universality of ICT in the SDGs suppress questions about the values and politics of ICT themselves, making their unsustainability invisible. A more integrative approach to ICT and sustainability is therefore warranted.

\section{The Doughnut}

\subsection{Ecological Ceiling}

In 2014, economist Kate Raworth, working at the time for the international organisation Oxfam, proposed the idea of 'Doughnut Economics' [17]. She was familiar with the Planetary Boundaries framework developed by Johan Rockström of the Stockholm Resilience Centre and Will Steffen of Australia National University [18, 19]. This framework is based on the idea of a finite planet. The nine planetary boundaries (see Fig. 1) are based on nine critical processes that together regulate the Earth's ca- 
pacity to sustain the Holocene, the geological epoch starting about 12.000 years ago and which contains the growth and impact of all species. The Planetary Boundaries framework is the most developed scientific tool we have at the moment to benchmark the impact of human activity on the planet. The framework considers the planet as an integrated system. Changes in processes forming one boundary can have a knock on effect in processes forming another boundary. At the moment, four boundaries are crossed (overshoot): climate change, nitrogen and phosphorus loading, land conversion, and biodiversity.

\subsection{Social Foundation}

Raworth recognised the importance of the Planetary Boundaries framework, but argued that adding social and economic aspects could contribute to creating a more holistic perspective. She formed two rings, the outer ring representing the Planetary Boundaries, or what she calls the "Ecological Ceiling", and the inner ring the "Social Foundation"; the effect was that of a doughnut (see Fig. 1). The space within the two rings is the "safe and just space for humanity" as well as the "regenerative and distributed economy". In particular the "safe and just space for humanity" integrates the planetary boundaries and social foundation. At the moment, all twelve key social and economic indicators (see Fig. 1) fall short of providing the necessary social foundation to all humans. In other words, large parts of the world's population are still lacking access to clean drinking, food, education or live under the poverty line.

The current situation of shortfalls and overshoots in the Doughnut gives urgent direction to sustainability in the life cycle of ICTs. The Doughnut illustrates that ICTs must, at a minimum, ensure they are not contributing to the effects that are causing us to overshoot our planet's ecological ceiling or undermine the social foundations of human welfare. Thus, while not undermining the positive role ICT can play in the transformation to sustainable development, the Planetary Boundary framework and the Doughnut make also clear that the social and environmental sustainability of ICT cannot be ignored.

Raworth has mapped the Sustainable Development Goals on the Doughnut and found a large overlap [20]. The SDGs cover all of the dimensions of the social foundations in its goals; the only exception is the Doughnut's dimension of "Political Voice", which is only covered in some SDG targets. Also in terms of ambition, the SDGs aim to end human deprivation is comparable to the social foundation of the Doughnut. Raworth is less optimistic when it comes to the ecological ceiling. The SDGs don't cover all dimensions or they do it in an unclear manner:

"Some are absolute and time-bound: end overfishing and halt deforestation by 2020. But two key ambitions - to halt biodiversity loss and combat climate change - lack target dates. And for others, the measure of success is unclear. What would it mean to 'significantly reduce' nutrient pollution by 2025 ? To 'minimize the release of' hazardous chemicals by 2030 ? Or to 'minimize the impacts of' ocean acidification (by no set date)?" [20] 


\subsection{ICT in a socio-ecological system}

Raworth's Doughnut is a visualization of a planetary and global socio-ecological system. It provides us with a space in which the social and the ecological are entangled. These entanglements are defined by two systems, which are still perceived as separate: the nine planetary boundaries, a product of Earth Systems research, and the social foundation, a product of the Janeiro $20+$ process, the process around the United Nations Conference on Sustainable Development, during which the process to develop the SDGs started. On the other hand, the Doughnut creates a space for integrative thinking and doing. This thinking and doing is no longer situated within one system or discipline or the other, but emerges from these two interrelated systems.

Nested within socio-ecological systems thinking, the Doughnut can strengthen integrative ways of thinking about ICT and sustainable development. Instrumentalist notions of ICT give way to critical and constructive understandings [16, 21, 22]. For example, that a mobile phone is produced in a way that uses child labor in the production of its materials or that has serious reproductive health consequences for the women workers assembling mobile phones, can not be cancelled out against the positive social or economic development mobile phones can provide.

A non-instrumentalist understanding of technology also opens up for inquiries that were buried down in ideas of universalism and neutrality, for example, who exactly will benefit from this safe and just space? Will only humans benefit from this safe and just space? In the next section I will explore these questions against the background of the notion of the Anthropocene.

\section{$4 \quad$ Life in the Ruins of Capitalism}

\subsection{Anthropocene}

The understandings of sustainability in the SDGs and the doughnut are firmly located in the discourse of the Anthropocene. This epoch, characterised by the dominant human influence on the planet, or the epoch in which human activities outcompete natural processes, is not yet formally accepted as a geological period. As a narrative, the Anthropocene has become an important marker for discussions around planetary boundaries, climate change, and sustainable development.

The term Anthropocene was popularised by Crutzen [23], who puts the start of the epoch at the end of the $18^{\text {th }}$ century, a date coinciding with the invention of the steam engine. The Executive Committee of the International Union of Geological Sciences has not yet ratified the proposal to accept the Anthropocene as a formal unit in the geological timescale, but the latest research (January 2018) puts the start of the Anthropocene in the Fall of 1965, based on peak levels in radio-active elements in both Northern and Southern hemispheres as a result of nuclear weapon testing [24]. This period coincides with a renewed focus on the environment; for example, Rachel Carson's Silent Spring [25], warning us of the destructive power of DDT, was published in 1962. The notion of the Anthropocene is thus associated with human activities that include sophisticated technologies. 
Critics of the term Anthropocene argue that the term hides more than it helps to make visible. Jason W. Moore proposed the term "Capitalocene" to replace the "Anthropocene's shallow historiciziation" [26]. Moore's critique includes the following elements:

- It is a-political in that it situates the start of the Anthropocene in 19th century Britain, with coal and steam as the main force: "Not class. Not capital. Not imperialism. Not even culture. But ... [...] humanity as an undifferentiated whole".

- It is based on a particular analytical logic that separates humanity of the web of life; humans are doing something to nature

Other critique comes from Malm and Hornborg, who argue that the Anthropocene narrative, coming from the natural sciences, has entered the social sciences and humanities, naturalising social relations, such as inequality between the species. As such, they argue, this narrative makes things more invisible than visible, and it prevents rather than stimulate action: "If global warming is the outcome of the knowledge of how to light a fire, or some other property of the human species acquired in some distant stage of its evolution, how can we even imagine a dismantling of the fossil economy?" [27]

Setting up humans against other species makes the tremendous inequalities found within humanity as a whole invisible, as well as hides the situation that large groups, marginalised in the global economy, are bearing the brunt of the effects of climate change and other ecological transformations. The naturalisation of social relations also affects the range of solutions possible. Proposals to deal with the unwanted effects of the Anthropocene are often technical, rather than political and social. Climate manipulations, geo-engineering, and ICT are seen as fixes of natural processes.

Raworth mapped the SDGs on the Doughnut, showing that they don't deal comprehensively with the environmental challenges that result in the overshoot of the planetary boundaries [20]. But while the Doughnut offers a more integrative approach to inform the ICT and sustainable development discourse, it is still firmly set within the discourse of the Anthropocene. As a consequence, there is a strong risk is that the unwanted differentiation between the sustainability of ICT and ICT for sustainability will continue. The dominance given to humans, in combination with the human capacity to design and use tools, will strengthen the instrumentalist ICT for sustainable development narrative. New visions and solutions, focusing more on the social and political entanglements of sustainable development, including the sustainability of ICT, will remain invisible.

\subsection{Staying with the Trouble in Multispecies Worlds}

Donna Haraway's most recent book, "Staying with the Trouble: Making kin in the Chthulucene" [28], is motivated by the dualistic thinking found in climate change discourses. At the one hand a techno-optimism, informed by the unshakeable trust that science and technology will get us out of our predicament, while on the other hand a cynical pessimism, which declares it is too late to do anything. The book ex- 
presses similar critique of the concept of Anthropocene as mention above, stressing that the term neatly divides the world in humans and the rest, ignoring our mutual becoming.

Haraway's approach is to tell stories that move beyond narratives of technooptimism and cynical pessimism, thus opening up a new space for more imaginary stories. These stories, about species entanglements in the 'Chthulucene', which are impossible in the Anthopocene's or Capitalocene's ontological certainties, open up for new possibilities:

"In urgent times, many of us are tempted to address trouble in terms of making an imagined future safe, of stopping something from happening that looms in the future, of clearing away the present and the past in order to make futures for coming generations. Staying with the trouble does not require such a relationship to times called the future. In fact, staying with the trouble requires learning to be truly present, not as a vanishing pivot between awful or edenic pasts and apocalyptic or salvific futures, but as mortal critters entwined in myriad unfinished configurations of places, times, matters, meanings" [28].

Haraway's stories of trouble involve mainly with dogs [29], but other critters, such trees, doves, and ants [28]. They are stories of making kin and multispecies. She shows how to "stay with the trouble" of ontological entanglements, that is, not to reduce this complexity to easy solutions, categories, and certainties. One of Haraway's concepts of trouble, the cyborg, which engages with ontological categories of gender, human, and technology, has been very productive as a story-telling and analytical device in ICT research [30-32]

Anna Tsing's latest book, "The Mushroom at the End of the World: On the Possibility of Life in Capitalist Ruins" presents a similar perspective as Haraway: "Making worlds is not limited to humans" [33]. Tsing starts her explorations in multispecies worlds with a similar critique on the notion of Anthropocene. She positions the timeline of the Anthropocene at the advent of modern capitalism, which "entangled us with ideas of progress and with the spread of the techniques of alienation that turned both humans and other beings into resources" [33].

Tsing describes how the notion of progress is embedded in how we understand what it means to be human: "[W]e learn over and over that humans are different from the rest of the world because we look forward" [33]. This means that nonhumans are also trapped in the temporal rhythm of progress, which Tsing calls the "driving beat" that drowns out other temporal rhythms [ibid.]. Tsing uses the musical term "polyphony" as a metaphor for how we can identify and listen to these individual temporal rhythms and at the same time experience their harmony and dissonance.

In her explorations of the polyphonic assemblage of human - mushroom relations, Tsing describes how people and mushrooms have found ways to survive on the margins and destructions of capitalism in the Anthropocene. While not offering a blueprint for collective survival, Tsing inspires us to listen better to the temporal rhythms of human and nonhuman actors in the ICT and sustainable development discourses and to find dissonance in harmony and harmony in dissonance. 


\subsection{Does this change anything?}

Haraway invites us to move beyond narratives of techno-optimism and cynical pessimism and Tsing proposes that we listen more seriously to the temporal rhythms of human and nonhuman actors. In the context of the ICT and sustainability, the question is: Does this change anything ${ }^{2}$ In what follows I present a brief reflection on how feminist technoscience can contribute to exploring existing binaries and categories found ICT and sustainability discourses.

Meet Agbogbloshie, a large scrap metal yard in Accra, Ghana, where I implemented fieldwork on repair and recycling as part of my research on the life cycle of mobile phones. Agbogbloshie is the place where cars, machines, and condemned electronics, such as mobile phones, are recycled. Non-metals parts that cannot be recycled, remain behind as untreated waste or are used as 'fuel' for the burning of cables that contain copper.

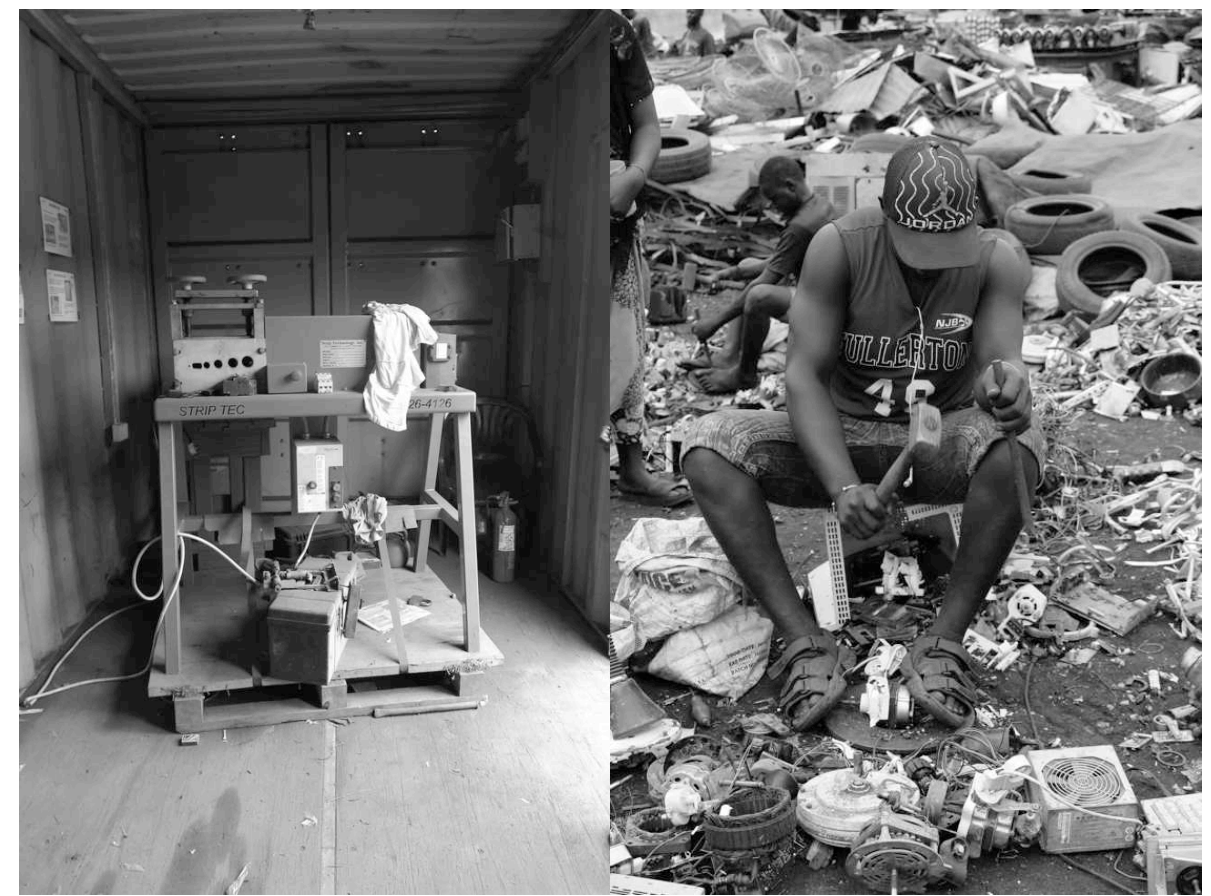

Fig. 3. Cable stripping machine (left) and electronics recycling (right) in the Agbogbloshie scrap metal yard (Photos: SMART/Maja van der Velden)

In the Western media, Agbogbloshie is often presented as the world's largest ewaste dump and as an environmental disaster, e.g., [34-38]. In reality, Agbogbloshie occupies only about one square kilometer. The yard and its surroundings (a household waste dump, river, wetland) are thoroughly polluted and the men and women working here have dangerously high levels of toxins in their blood (see Fig. 3) [39, 40]. At the

\footnotetext{
${ }^{2}$ Reference to the overall theme of the conference: "This changes everything".
} 
same time, the activities in and around the yard have created thousands of jobs [41]. Many of the young men doing the most strenuous low-paid work come from northern Ghana, who use this work as an entry point into the urban economy [42]. Climate change plays an important role in their migration to Accra [43]. The workers of Agbogbloshie produce spare parts for the repair of electronics, cars, bicycles, etc., thus extending their lifespan, and a large amount of the recycled metals are sold to national and international companies that re-use them.

The lenses offered by Haraway and Tsing provide a particular layer of analysis. While the Western media and scholars strengthen the driving beat of environmental destruction, more careful observations bring out what Tsing's calls a polyphonic assemblage: the daily rhythm of work, such as the ongoing 'banging' of tools on metal heard all over the yard and the cooking selling of food and water by women; the rhythm of the animals living of the debris, such as the birds in the river and cows and goats grazing on the plain of household waste next to the yard; the rhythms of obsolescence of consumer electronics in rich countries and the import of legal and illegal second-hand electronics in Ghana; the rhythms of international scrap metal prices, which regulate many of the activities in the yard; and not to forget the rhythm of the seasons that expose climate changes and bring new waves of young people to Agbogbloshie. Paying close attention to these individual rhythms and staying with the trouble of informal e-waste recycling may offer new insight in how to deal with e-waste in countries that have no sustainable e-waste recycling facilities.

Presenting Agbogbloshie's problems as the result of the illegal dumping of e-waste from rich countries creates a particular scenario in which only binaries are presented, such as the rich versus poor and exploiting versus exploited. Such stories often ignore Ghana's domestic ICT market, which played a central role in its economic development, and produce solutions, such as mechanization (cable-stripping machines, see Fig. 3) and industrialization, without considering global entanglements. For example, understanding why young men at Agbogbloshie still prefer burning the cables, while cable-stripping machines are available, is a complex story in which there are no clear perpetrators and victims. ${ }^{3}$ Haraway thus warns against telling restrictive stories: "it matters what stories tell stories" [28]. Staying with the trouble is about "story-telling for earthly survival", Haraway argues, stories that are situated in the now, stories of a thick ongoing presence, not an instantaneous presence [28, 44].

The purpose of this brief reflection on Agbogbloshie is to highlight that a more integrative approach can open up new ways of understanding the relation between ICT and sustainability. Tsing and Haraway remind us that ICT and sustainability is about the mutual becoming of humans and technology. Rather than promoting dualistic thinking, dividing the field into or ICT for sustainability and sustainable ICT, we can

\footnotetext{
${ }^{3}$ I talked with several of the young men burning cables. Their daily earnings are so low, depending on the price the middlemen are willing to pay, that they don't want to spend any money on electricity for running the machine. They als mention that operating the machine takes time; time they prefer to spend on collecting cables. Observing their work, I noticed they used plastic components from e-waste and isolation from old fridges as fuel for the fires. It takes about a minute to burn a kilo of cables. The thick smoke from the fires contains dangerous toxins, creating serious health risks.
} 
look for contact zones, spaces of dissonance within each and harmony between both. What we will find there are stories in which human, nonhumans, and earthly survival are collaboratively entangled. However, as long as we situated humans in the center of our stories, ICT will be understood as man's neutral tool that can be used for good or for bad. By bestowing man with ICT the agency for change, we remain caught in the predicament of the Anthropocene, literally and figuratively.

\section{$5 \quad$ Concluding Remarks}

The discourse on ICT and sustainable development is characterized by two divergent thoughts; ICT is perceived as both an enabler of sustainable development as well as a producer of unsustainability, because of the social and environmental impacts found in the life cycles of ICTs. The notion of ICT as an enabler or facilitator is based on an instrumentalist understanding of technology, in which technology is perceived as a neutral tool, ready to be used by man for good or bad. This driving beat is strengthened by the human-centeredness underlying the sustainable development discourse as well as the human-centered narrative of the Anthropocene.

The example of electronics recycling in Ghana showed the entanglement of the two discourses. The work of feminist scholars, who invite us to both imagine different figurations and futures in the thick ongoing presence (Haraway) and to pay attention to local practices, often found in the margins of Anthropocene capitalism (Tsing), can help us to overcome telling restrictive stories. The resulting decentering of man and re-politicizing of ICT opens up for new ways of engaging with ICT and sustainability.

Lastly, the Anthropocene is more than a geological epoch based on measurements of human impact on the planet. We can also identify a technological Anthropocene, an epoch in which technology is understood as the facilitator of progress and growth. The dominant discourse or beat, that more technology will get us out of this predicament and will bring sustainable development, needs both refinement and critical investigation.

\section{Acknowledgement}

I would like to thank the two anonymous reviewers for their helpful comments; Anna Croon for asking about the nonhumans in the doughnut; Dr. Martin Oteng-Ababio, my SMART colleague in Ghana; and my fellow travelers to Ghana, Hanne Cecilie Geirbo and Alice Frantz Schneider. This paper is written as part of SMART, a Horizon2020-financed research project (grant agreement no. 693642).

\section{References}

1. Raworth K (2017) A Doughnut for the Anthropocene: humanity's compass in the 21st century. Lancet Planet Health 1:e48-e49 
2. United Nations (2018) Sustainable Development Goals. In: U. N. Sustain. Dev. http://www.un.org/sustainabledevelopment/sustainable-development-goals/. Accessed 2 Feb 2018

3. van der Velden M, Taylor MB (2017) Sustainability Hotspots Analysis of the Mobile Phone Lifecycle. University of Oslo, Oslo. Online: https://zenodo.org/record/1146844. Accessed 30 Nov 2017

4. Raworth K (2012) A safe and just space for humanity: can we live within the doughnut. Oxfam Policy Pract Clim Change Resil 8:1-26

5. van der Velden M (2018) Design for Living in the Doughnut. In: Proceedings of Relating Systems Thinking and Design (RSD6) 2017 Symposium. Oslo Online: https:/systemic-design.net/wp-content/uploads/2017/12/Maja-van-der-Velden-RSD6working-paper.pdf Accessed 30 Nov 2017

6. United Nations (2016) ICTs as a catalyst for sustainable development: Sustainable Development Knowledge Platform. Online:

https://sustainabledevelopment.un.org/index.php Accessed 30 Jan 2018

7. SustainAbility (2018) How ICT Can Deliver the SDGs. In: SustainAbility. http://sustainability.com/our-work/case-studies/how-ict-can-deliver-the-sdgs/. Accessed 30 Jan 2018

8. ITU (2018) ICTs for a Sustainable World \#ICT4SDG Toolkit. Online: http://www.itu.int:80/en/sustainable-world/Pages/toolkit.aspx. Accessed 30 Jan 2018

9. de Haan E, Scheele F, Kiezebrink V (2016) Cobalt blues: Environmental pollution and human rights violations in Katanga's copper and cobalt mines. SOMO, Amsterdam

10. China Labour Watch, Future in Our Hands (2015) Something's Not Right Here: Poor working conditions persist at Apple supplier Pegatron. Future in Our Hands, Oslo

11. Bafilemba F, Lezhnev S (2015) Congo's Conflict Gold Rush: Bringing Gold into the Legal Trade in the Democratic Republic of the Congo. Enough Project, Washington

12. Asia Monitor Resource Centre (2013) Labour Rights in High Tech Electronics: Case Studies of Workers' Struggles in Samsung Electronics and its Asian Suppliers. AMRC, Hong Kong

13. Human Rights Watch (2015) Precious Metal, Cheap Labor: Child Labor and Corporate Responsibility in Ghana's Artisanal Gold Mines. HRW, Washington

14. Brown JH (2015) The Oxymoron of Sustainable Development. BioScience 65:10271029

15. Patrignani N, Whitehouse D (2014) Slow Tech: a quest for good, clean and fair ICT. J Inf Commun Ethics Soc 12:78-92

16. Feenberg A (2002) Transforming Technology: A Critical Theory Revisited. Oxford University Press, Oxford

17. Raworth K (2017) Doughnut Economics: Seven Ways to Think Like a 21st-Century Economist. Chelsea Green Publishing

18. Rockström J, Steffen W, Noone K, et al (2009) Planetary Boundaries: Exploring the Safe Operating Space for Humanity. Ecol Soc 14:

19. Steffen W, Richardson K, Rockström J, et al (2015) Planetary boundaries: Guiding human development on a changing planet. Science 347:1259855.

20. Raworth K (2014) Will these Sustainable Development Goals get us into the doughnut (aka a safe and just space for humanity)? In: Poverty Power. http://oxfamblogs.org/fp2p/will-these-sustainable-development-goals-get-us-into-thedoughnut-aka-a-safe-and-just-space-for-humanity-guest-post-from-kate-raworth/. Accessed 7 Sep 2016

21. Verbeek P-P (2006) Materializing Morality Design Ethics and Technological Mediation. Sci Technol Hum Values 31:361-380

22. Akrich M (1992) The De-scription of Technical Objects. In: Bijker W, Law J (eds) Shaping Technology. MIT Press, Cambridge, pp 205-224 
23. Crutzen PJ (2006) The "Anthropocene.” In: Ehlers PDE, Krafft DT (eds) Earth System Science in the Anthropocene. Springer Berlin Heidelberg, pp 13-18

24. Turney CSM, Palmer J, Maslin MA, et al (2018) Global Peak in Atmospheric Radiocarbon Provides a Potential Definition for the Onset of the Anthropocene Epoch in 1965. Sci Rep 8:3293

25. Carson R (1962) Silent Spring. Mariner Books, Boston

26. Moore JW (2017) The Capitalocene, Part I: on the nature and origins of our ecological crisis. J Peasant Stud 44:594-630

27. Malm A, Hornborg A (2014) The geology of mankind? A critique of the Anthropocene narrative. Anthr Rev 1:62-69

28. Haraway D (2016) Staying with the Trouble: Making Kin in the Chthulucene. Duke Univ Pr, Durham

29. Haraway D (2008) When Species Meet. University of Minnesota Press, Minneapolis

30. Markussen R (1996) Politics of intervention in design: feminist reflections on the Scandinavian tradition. Ai Soc 10:127-141

31. Ehrnberger K, Broms L, Katzeff C (2013) Becoming The Energy Aware Clock - Revisiting The Design Process Through A Feminist Gaze. Exp Des Res 2013 5:

32. van der Velden M (2008) What's Love Got To Do With IT? On ethics and accountability in telling technology stories. In: Sixth International Conference on Cultural Attitudes towards Technology and Communication. University of Nîmes, Nîmes, France

33. Tsing AL (2015) The Mushroom at the End of the World: On the Possibility of Life in Capitalist Ruins. Princeton University Press, Princeton

34. Tue NM, Goto A, Takahashi S, et al (2016) Release of chlorinated, brominated and mixed halogenated dioxin-related compounds to soils from open burning of e-waste in Agbogbloshie (Accra, Ghana). J Hazard Mater 302:151-157

35. Chama MA, Amankwa EF, Oteng-Ababio M (2014) Trace metal levels of the Odaw river sediments at the Agbogbloshie e-waste recycling site. J Sci Technol Ghana 34:1-8

36. BBC (2017) Insider: Reggie Yates - A Week in a Toxic Waste Dump. Online: https://www.youtube.com/watch?v=3IPqgy2K8RI. Accessed 24 Feb 2018

37. Briefing RLT for B (2017) Australian e-waste ending up in toxic African dump, torn apart by children. In: ABC News. http://www.abc.net.au/news/2017-03-10/australian-ewaste-ending-up-in-toxic-african-dump/8339760. Accessed 29 Apr 2018

38. McElvaney K Ghana's e-waste magnet. https://www.aljazeera.com/indepth/inpictures/2014/01/pictures-ghana-e-waste-mecca2014130104740975223.html. Accessed 29 Apr 2018

39. Srigboh RK, Basu N, Stephens J, et al (2016) Multiple elemental exposures amongst workers at the Agbogbloshie electronic waste (e-waste) site in Ghana. Chemosphere 164:68-74 . doi: 10.1016/j.chemosphere.2016.08.089

40. Amankwaa EF, Adovor Tsikudo KA, Bowman J (2017) 'Away' is a place: The impact of electronic waste recycling on blood lead levels in Ghana. Sci Total Environ 601:1566-1574 . doi: 10.1016/j.scitotenv.2017.05.283

41. Goldwater S (2014) Regolith. Online: https://vimeo.com/107800720 Accessed 24 Feb 2018

42. Oteng-Ababio MM, Amankwaa EF (2014) The e-waste conundrum: Balancing evidence from the North and on-the-ground developing countries' realities for improved management. Afr Rev Econ Finance 6:181-204

43. Fielmua N, Gordon D, Mwingyine DT (2017) Migration as an Adaptation Strategy to Climate Change: Influencing Factors in North-western Ghana. J Sustain Dev 10:155

44. Yale University (2017) Donna Haraway - "Making Oddkin: Story Telling for Earthly Survival." New Haven. Online: https://www.youtube.com/watch?v=z-iEnSztKu8 Accessed 24 Feb 2018 